\title{
Mobility of black carbon in drained peatland soils
}

\author{
J. Leifeld ${ }^{1}$, S. Fenner ${ }^{1}$, and M. Müller ${ }^{2}$ \\ ${ }^{1}$ Air Pollution/Climate Group, Agroscope Reckenholz-Tänikon Research Station ART, Zurich, Switzerland \\ ${ }^{2}$ Bern University of Applied Sciences, Swiss Collage of Agriculture, Zollikofen, Switzerland
}

Received: 8 March 2007 - Published in Biogeosciences Discuss.: 23 March 2007

Revised: 18 June 2007 - Accepted: 23 June 2007 - Published: 27 June 2007

\begin{abstract}
Amount, stability, and distribution of black carbon (BC) were studied at four sites of a large peatland ("Witzwil") formerly used as a disposal for combustion residues from households to derive $\mathrm{BC}$ displacement rates in the profile. Possible artefacts from thermal oxidation with Differential Scanning Calorimetry (DSC) on BC quantification of C-rich deposits were inferred by choosing three sites from a second peatland with no historical record of waste disposal as a reference ("Seebodenalp"). All sites were under grassland at time of sampling, but were partially cropped in the past at Witzwil. Mean BC contents in topsoils of Witzwil ranged from 10.7 to $91.5(0-30 \mathrm{~cm})$ and from 0.44 to 51.3 (30-140 cm) $\mathrm{mg} \mathrm{BC} \mathrm{g}^{-1}$ soil, corresponding to $\mathrm{BC} / \mathrm{OC}$ ratios of 0.04 to 0.3 (topsoil) and 0.02 to 0.18 (deeper soil). At three sites of Seebodenalp, BC was below the detection limit of $0.4 \mathrm{mg} \mathrm{g}^{-1}$ organic soil, indicating negligible formation of $\mathrm{BC}$ during thermal oxidation of peat. ${ }^{13} \mathrm{C}$ NMR spectra corroborated the high $\mathrm{BC}$ contents at Witzwil. The data support a considerable vertical transport of $\mathrm{BC}$ given that soils were ploughed not deeper than $30 \mathrm{~cm}$ since abandonment of waste application about 50 years ago. The total amount of $\mathrm{BC}$ in the Witzwil profiles ranged from 3.2 to $7.5 \mathrm{~kg} \mathrm{BC} \mathrm{m}^{-2}$, with 21 to 69 percent of it stemming from below the former ploughing depth. Under the premise of negligible rates of BC consumption since abandonment of waste application, minimum BC transport rates in these peats are 0.6 to $1.2 \mathrm{~cm} \mathrm{a}^{-1}$. The high mobility of BC might be explained by high macropore volumes in combination with occasional water saturation. By means of DSC peak temperatures, different types of $\mathrm{BC}$ could be distinguished, with deeper horizons containing $\mathrm{BC}$ of higher thermal stability. Application of combustion residues likely involved a mixture of various $\mathrm{BC}$ types, of which thermally more stable ones, most likely soots, were preferentially transported downwards.
\end{abstract}

Correspondence to: J. Leifeld

(jens.leifeld@art.admin.ch)

\section{Introduction}

Black or pyrogenic carbon (BC) is considered an important part of the global carbon cycle (Kuhlbusch, 1998). In ecosystems, it is mainly produced from incomplete combustion of plants both as chars and as soots with regionally varying contributions from residues of fossil fuel burning (e.g. Gustafsson et al., 2001). It has been stated that BC is part of the biochemically and chemically stable aromatic fraction of soil organic matter though it is not inert. Recent studies indicated that $\mathrm{BC}$ is both chemically and microbially oxidized in soil (Cheng et al., 2006; Hockaday et al., 2006) though at a smaller rate than more active compounds of SOM. With the increasing evidence of the decomposability of $\mathrm{BC}$, its mobility in soil becomes an important issue, because different allocations in the soils' profile provide different environments for microbial activity, oxygen supply and thus BC oxidation.

Carcaillet (2001) estimated for sites in the French Alps, that the major part of charcoal particles above a diameter of $400 \mu \mathrm{m}$ was buried at a depth of 40 to $70 \mathrm{~cm}$ only after 2500 to 6000 years. Dai et al. (2005) reported on translocation of $\mathrm{BC}$ in a temperate mixed-grass savanna to a depth of 10 to $20 \mathrm{~cm}$ with in a few years. Skjemstad et al. (1999) concluded that charcoal is redistributed in soil profiles under sugarcane down to a depth of 50 to $60 \mathrm{~cm}$ and hypothesised, that the migration may be favoured in coarse-textured soil, but could not give a transport rate because of the unknown pre-experimental BC contents in the deeper soil horizons. For a slash and burn system in Laos, Rumpel et al. (2006) showed BC to occur in the soil down to $60 \mathrm{~cm}$ with a declining ratio of $\mathrm{BC}$ to $\mathrm{OC}$ with depth. All these studies suggest that $\mathrm{BC}$ is mobile in mineral soils, but data on the rate of transportation is scarce. Moreover, none of these studies has addressed the fate of $\mathrm{BC}$ in organic soils.

Determination of $\mathrm{BC}$ transport rates in soil is complicated by the often uncertain history of $\mathrm{BC}$ input and land-use. Here, we estimated $\mathrm{BC}$ transport rates by making use of the

Published by Copernicus Publications on behalf of the European Geosciences Union. 
historical practice of depositing substantial amounts of pyrogenic carbon onto a large, agriculturally used peatland area in Switzerland. The period and technique of application is known with high confidence, providing an opportunity to infer the mobility of $\mathrm{BC}$ in organic soils.

\section{Sites and methods}

\subsection{Sites}

The Witzwil peatland $\left(47^{\circ} 59^{\prime} 33^{\prime \prime} \mathrm{N}, 7^{\circ} 03^{\prime} 51^{\prime \prime} \mathrm{E}\right)$ is the largest fen area in Switzerland covering 986 ha, located at around $430 \mathrm{~m}$ above sea level. The site is a relatively flat, peat-covered alluvial deposit located between Lake Neuchâtel, Lake Murten, and Lake Biel having a MAT of $9.1^{\circ} \mathrm{C}$ and a MAP of $994 \mathrm{~mm}$. Since 1868 , the area has been drained and hydrological engineering measures were taken to stop the regular flooding of large parts of the agricultural land and accompanying forests. Since that time, subsidence rates of more than two meters were recorded along many transects in Witzwil, indicating a pronounced loss of peat due to biological oxidation in combination with compaction and shrinkage. From the beginning of the twentieths century, since 1914, many soils in Witzwil were used as a deposit for waste and combustion residues from households and from the waste management plant of the city of Bern (aimed at improving the soils fertility) until around 1954 (GutknechtMäder 1998). The two main fuels at that time were wood and coal. Still today, some residues of that practice, such as metal, charred coal, or cinders from coal gasification can be found in the topsoil. Deep-ploughing is a common measure to mix the organic horizons with the mineral material below the peat in order to improve the hydrological properties of the peat and to reduce oxidation rates. At Witzwil, soils were deep-ploughed occasionally in the past, but not everywhere. Based on historical records and evaluation of the soil profiles in the field, none of our sampling sites were affected by this practice.

Four sites at Witzwil (hereafter referred to as W1, W2, W3, W4) were sampled in summer 2006. Sites are at around one to three $\mathrm{km}$ distance to each other. Sites were under grassland at time of sampling, but have been used as cropland in earlier times, as indicated by a distinct former ploughing horizon (Hp). At each site, a three meter wide profile was opened with the help of a mechanical digger with a scoop, and four vertical replicates were sampled horizon-wise at a distance of $0.5 \mathrm{~m}$ each (total $\mathrm{N}=100$ ). In addition, five to six soil cores $(100 \mathrm{ml}, \mathrm{N}=151)$ were taken from each horizon for determination of bulk density and pore volume. Profiles were sampled down to the deepest peat horizon, i.e. between $30 \mathrm{~cm}$ (W4) and $140 \mathrm{~cm}$ (W1). The current depth of the peat is a result of subsidence and pristine peat thickness and varies considerably within the area.
Seebodenalp $\left(47^{\circ} 05^{\prime} 38^{\prime \prime} \mathrm{N}, 8^{\circ} 45^{\prime} 35^{\prime \prime} \mathrm{E}\right)$ is a peatland at an elevation of around $1025 \mathrm{~m}$ above sea level and has been drained around 120 years ago. It is historically used as permanent grassland with a mixture of haying and grazing. Thirty-nine samples were cored in 2004 at three different sites (hereafter referred to as $\mathrm{S} 1-\mathrm{S} 3$ ) from the upper $30 \mathrm{~cm}$. $\mathrm{S} 1$ is a bog, and S2 and S3 are fens similar to those at Witzwil. Sites $S 1$ to $S 3$ are at around 0.5 to $1 \mathrm{~km}$ distance to each other.

\subsection{Methods}

Samples for chemical analysis were dried at $105^{\circ} \mathrm{C}$, weighed, milled, and organic $\mathrm{C}$ and total $\mathrm{N}$ were determined by dry combustion in an elemental analyzer (Hekatech, Germany). Samples were free of carbonate apart from deeper horizons of $\mathrm{W} 2$, which were treated with $1 \mathrm{M} \mathrm{HCl}$ before carbon quantification. Black carbon was measured as thermally stable organic matter burning at temperatures of $520^{\circ} \mathrm{C}$ or above (heating rate $20^{\circ} \mathrm{C} \mathrm{min}^{-1}$ ) in a Differential Scanning Calorimeter (DSC, TA Instruments) as described in Leifeld (2007). The amount of BC in the sample is linearly related to the peak height in the thermogram with a similar slope for charcoal and soot, and thermally more labile BC species (e.g. charcoal) can be distinguished from stable forms (e.g. soot) by means of the $\mathrm{BC}$ peak temperature. The detection limit for the heat flow of this method is $0.1 \mathrm{~mW}$ or $0.0012 \mathrm{mg} \mathrm{BC}$ for organic samples, corresponding to $0.4 \mathrm{mg} \mathrm{BC} \mathrm{g}^{-1}$ soil for a C-rich sample with a sample weight of $3 \mathrm{mg}$.

${ }^{13} \mathrm{C}$ CPMAS NMR (cross-polarization magic angle spinning nuclear magnetic resonance) spectra were recorded at the NMR facility of the Technical University Munich (Bruker DSX 200 NMR spectrometer, Bruker, Karlsruhe, Germany; resonance frequency $50.32 \mathrm{MHz}$, contact time $1.0 \mathrm{~ms}$, pulse delay $150 \mathrm{~ms}$, magic angle spinning speed $6.8 \mathrm{kHz}$ ). For each sample, between 5000 and 20000 scans were accumulated. The ${ }^{13} \mathrm{C}$ chemical shifts were calibrated relative to tetramethylsilane $(0 \mathrm{ppm})$. Peaks were assigned to functionalities according to Knicker and Lüdemann (1995).

Soil bulk density was determined by taking five to six replicated samples per soil horizon using $100 \mathrm{ml}$ soil cores. Samples were dried to $105^{\circ} \mathrm{C}$ and weighed. The total soil pore volume was calculated as the difference in weight between the water-saturated and the oven-dried sample.

Correlation between soil physical attributes and SOC content are described using Spearman's rank correlation coefficient.

\section{Results}

\subsection{Soil physics and organic carbon}

Soil pore volume increased from approximately $65 \%$ in the topsoil to around $90 \%$ at the bottom of the deep peat profiles $\mathrm{W} 1$ and $\mathrm{W} 3$ (Table 1). Large pore volumes of $>80 \%$ 
Table 1. OC content, bulk density and pore volume for all sites ( $\pm 1 \mathrm{SE})$.

\begin{tabular}{|c|c|c|c|c|}
\hline site & mean depth $(\mathrm{cm})$ & $\operatorname{SOC}\left(\mathrm{mg} \mathrm{g}^{-1}\right.$ soil $)$ & bulk density $\left(\mathrm{g} \mathrm{cm}^{-3}\right)$ & pore volume (\%) \\
\hline \multirow[t]{8}{*}{ W1 } & 10 & $265.5(13.3)$ & $0.65(0.02)$ & $64.4(0.5)$ \\
\hline & 20 & $253.5(14.7)$ & $0.60(0.02)$ & $66.7(0.4)$ \\
\hline & 30 & $440.6(41.3)$ & $0.56(0.04)$ & $69.3(1.5)$ \\
\hline & 50 & $382.5(37.2)$ & $0.18(0.02)$ & $86.3(0.4)$ \\
\hline & 65 & $329.6(47.2)$ & $0.22(0.02)$ & $86.2(0.8)$ \\
\hline & 80 & $427.6(40.0)$ & $0.17(0.01)$ & $88.9(0.2)$ \\
\hline & 105 & $484.5(48.6)$ & $0.11(0.01)$ & $91.2(0.5)$ \\
\hline & 135 & $482.4(41.3)$ & $0.11(0.01)$ & $91.1(0.2)$ \\
\hline \multirow[t]{6}{*}{ W2 } & 10 & $245.4(7.4)$ & $0.67(0.01)$ & $65.5(0.3)$ \\
\hline & 20 & $250.2(8.0)$ & $0.62(0.02)$ & $67.3(1.0)$ \\
\hline & 41 & $331.0(21.1)$ & $0.30(0.03)$ & $75.2(1.0)$ \\
\hline & 52 & $53.7(5.9)$ & $0.95(0.09)$ & $57.7(0.5)$ \\
\hline & 57 & $212.4(20.4)$ & $0.53(0.03)$ & $77.1(1.1)$ \\
\hline & 85 & $20.9(0.87)$ & $1.20(0.05)$ & $57.2(0.4)$ \\
\hline \multirow[t]{8}{*}{ W3 } & 10 & $314.0(3.3)$ & $0.62(0.02)$ & $65.1(0.3)$ \\
\hline & 20 & 300.5 (11.4) & $0.60(0.02)$ & $65.2(0.5)$ \\
\hline & 35 & $286.3(9.3)$ & $0.38(0.01)$ & $75.2(0.8)$ \\
\hline & 50 & $367.0(18.8)$ & $0.19(0.01)$ & $87.8(0.4)$ \\
\hline & 65 & $503.8(17.4)$ & $0.13(0.01)$ & $90.8(0.2)$ \\
\hline & 85 & $266.6(25.9)$ & $0.51(0.04)$ & $70.6(0.4)$ \\
\hline & 105 & $533.1(3.9)$ & $0.11(0.01)$ & $91.4(0.1)$ \\
\hline & 125 & $511.2(18.1)$ & $0.12(0.01)$ & $91.2(0.2)$ \\
\hline \multirow[t]{4}{*}{ W4 } & 2.5 & 307.1 (1.8) & $0.62(0.02)$ & $62.4(0.6)$ \\
\hline & 5 & 302.5 (3.6) & $0.61(0.02)$ & $62.6(0.7)$ \\
\hline & 15 & 307.7 (2.8) & $0.62(0.02)$ & $61.8(0.5)$ \\
\hline & 25 & $305.1(5.1)$ & $0.62(0.02)$ & $60.4(1.2)$ \\
\hline \multirow[t]{5}{*}{$\mathrm{S} 1$} & 2 & 455.7 (12.4) & $0.15(0.03)$ & $86.8(7.3)$ \\
\hline & 6 & $478.9(12.4)$ & $0.23(0.01)$ & $84.7(1.4)$ \\
\hline & 14 & $501.0(13.2)$ & $0.16(0.03)$ & $89.9(2.6)$ \\
\hline & 22 & $508.4(7.8)$ & $0.12(0.02)$ & $88.5(1.7)$ \\
\hline & 34 & $531.9(3.9)$ & $0.10(0.01)$ & $92.2(1.6)$ \\
\hline \multirow[t]{4}{*}{$\mathrm{S} 2$} & 2 & $336.1(7.1)$ & $0.19(0.03)$ & $86.0(1.1)$ \\
\hline & 6 & 338.0 (26.9) & $0.24(0.02)$ & $88.5(1.8)$ \\
\hline & 14 & $420.3(41.6)$ & $0.22(0.05)$ & $88.3(2.4)$ \\
\hline & 22 & $476.9(7.9)$ & $0.16(0.04)$ & $74.6(2.1)$ \\
\hline \multirow[t]{4}{*}{ S3 } & 2 & $189.9(12.0)$ & $0.33(0.02)$ & $69.4(4.7)$ \\
\hline & 6 & $146.3(13.1)$ & $0.55(0.03)$ & $68.1(1.1)$ \\
\hline & 14 & $217.7(63.7)$ & $0.40(0.07)$ & $74.9(1.4)$ \\
\hline & 22 & $148.8(31.8)$ & $0.30(0.05)$ & 84.2 (1.9) \\
\hline
\end{tabular}

were also observed at the shallow profiles S1 and S2. Profile W2 revealed smaller pore volumes and correspondingly higher bulk densities in two interlayers. Soil pore volume was highly significantly and linearly correlated to the soils bulk density ( $r=-0.91$ ), and both pore volume and bulk density correlated with SOC content $(r=0.57$ and -0.81 , respectively). The power of these correlations increased when the two sites W and S were analyzed separately. Minimum bulk densities of around $0.11 \mathrm{~g} \mathrm{~cm}^{-3}$ and correspondingly large pore volumes as observed below $20 \mathrm{~cm}$ at the bog site $\mathrm{S} 1$ and in the deep horizons of W1 and W3 may be close to the physical conditions of the pristine peat.

Organic carbon contents at W1 to W4 ranged between 200 and $500 \mathrm{mg} \mathrm{g}^{-1}$ soil for most sites apart from two mineral interlayers at W2 with OC contents of below $100 \mathrm{mg} \mathrm{g}^{-1}$, referring to the fen origin of these histosols (Table 1). Smaller OC contents in the W2 interlayers coincided with smaller pore volumes. At S1 and S2, the topsoil contained more OC 

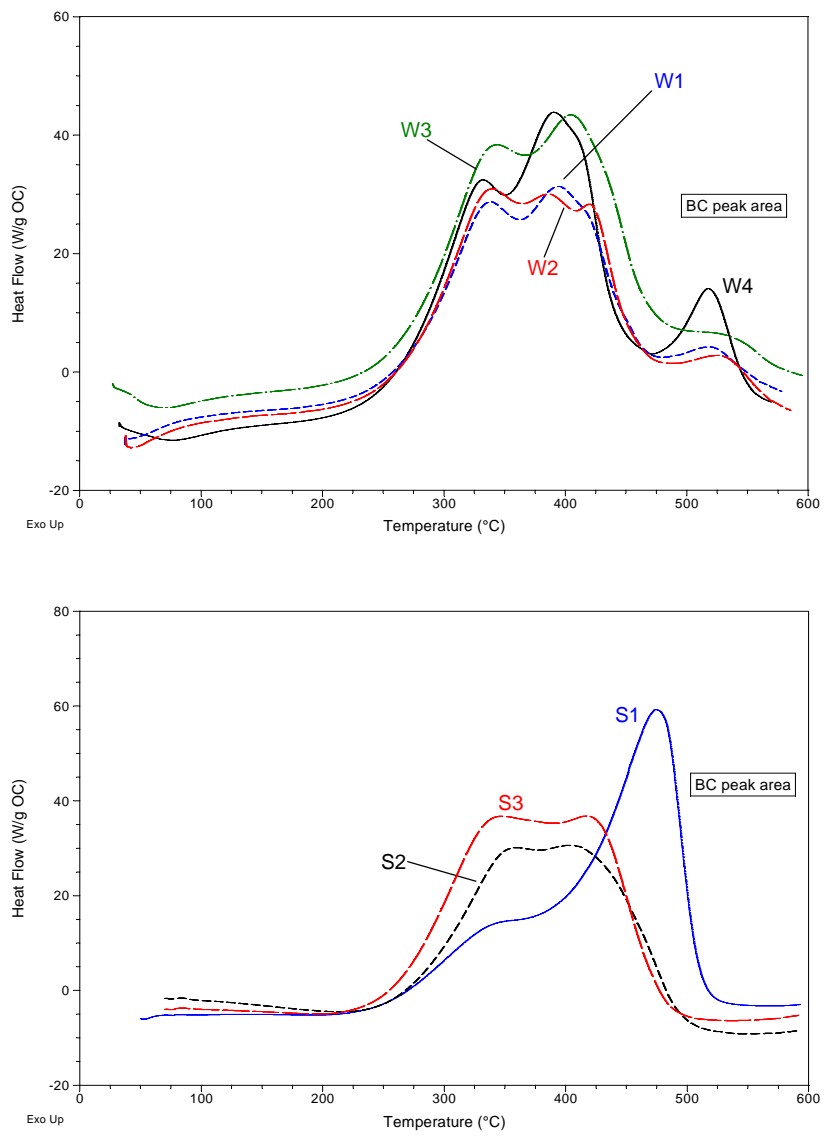

Fig. 1. Thermograms of peat from the top $25 \mathrm{~cm}$ from Witzwil (upper panel, W1 short-dash, W2 long-dash, W3 dash-dot, W4 solid) and Seebodenalp (lower panel, S1 solid, S2 short-dash, S3 longdash). OC contents of these samples range from 24 to 31 percent at Witzwil and from 31 to 41 percent at Seebodenalp. Heat flows are normalized to OC contents.

than horizons of similar depth at Witzwil, probably indicating weaker peat degradation at Seebodenalp. Site S3 had comparable small OC contents which were likely caused by the small distance of this site to adjacent mineral soils. OC contents between 400 and $500 \mathrm{mg} \mathrm{g}^{-1}$ soil refer to largely intact or only slightly decomposed peat. The degree of decomposition was also visible in the field as identifiable plant tissue (fibric structure) for most samples from Seebodenalp and in the deeper Witzwil horizons where both, wood and sedges could be identified. In the former ploughing horizon at Witzwil, OC contents ranged from 200 to $300 \mathrm{mg} \mathrm{g}^{-1}$ soil only, likely reflecting the ongoing decomposition of the peat, because this material was also medium to fine-textured. However, as for W2, mineral interlayers may also have contributed to the smaller OC contents.

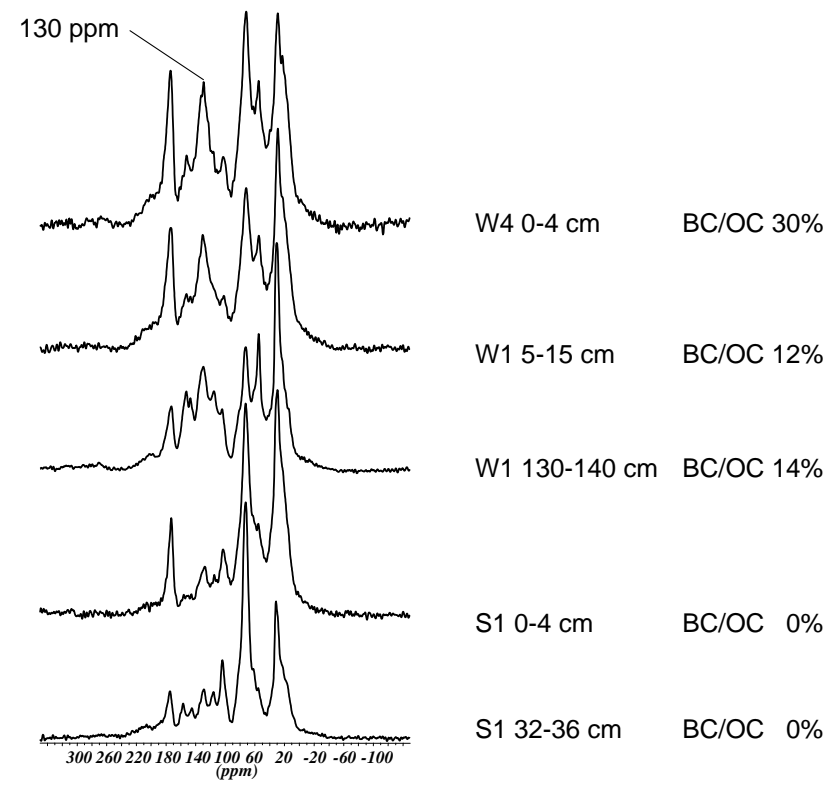

Fig. 2. ${ }^{13} \mathrm{C}$ NMR spectra from two $\mathrm{BC}$-containing samples at Witzwil (upper spectra) and two BC-free samples from Seebodenalp (bottom). Sample name and $\mathrm{BC} / \mathrm{OC}$ ratios (\%) are given in the plot.

3.2 Thermograms and NMR spectra of Witzwil and Seebodenalp

Typical burning patterns of topsoils $0-25 \mathrm{~cm}$ from W1-W4 and $\mathrm{S} 1-\mathrm{S} 3$ are given in Fig. 1. Witzwil soils are characterized by various non-BC peaks at temperatures below $500^{\circ} \mathrm{C}$ and peaks of different magnitude at temperatures of $520^{\circ} \mathrm{C}$ and higher which can be assigned to $\mathrm{BC}$ or coal. A single piece of charred bituminous coal found in the upper horizon of W2 peaked at $573^{\circ} \mathrm{C}$. In contrast, Seebodenalp soils almost exclusively consist of peaks in the non-BC region up to $500^{\circ} \mathrm{C}$. NMR spectra of all samples showed distinct peaks in the alkyl-C, O-alkyl-C, and carboxyl-C region that are characteristically for soil organic matter (Fig. 2). The NMR spectra of three samples from Witzwil were in addition characterized by a broad peak at $130 \mathrm{ppm}$ typical for aromatic moieties not substituted by oxygen while spectra from Seebodenalp had only a weak signal in that spectral region. From the thirtynine samples from Seebodenalp, only one contained BC at a concentration of $5.2 \mathrm{mg} \mathrm{BC} \mathrm{g}^{-1}$ soil while the others were below the detection limit. The following quantitative analysis is therefore limited to the Witzwil sites.

\subsection{Black carbon}

Black carbon concentrations in Witzwil profiles as derived from DSC measurements ranged from 10 to $51,<1$ to 30 , 12 to 48 , and 89 to $93 \mathrm{mg} \mathrm{BC} \mathrm{g}^{-1}$ soil for W1-W4, respectively, corresponding to $\mathrm{BC} / \mathrm{OC}$ ratios of 0.02 to 0.18 (W1 to W3) and around 0.3 (W4) (Figs. 3 and 4). BC contents 


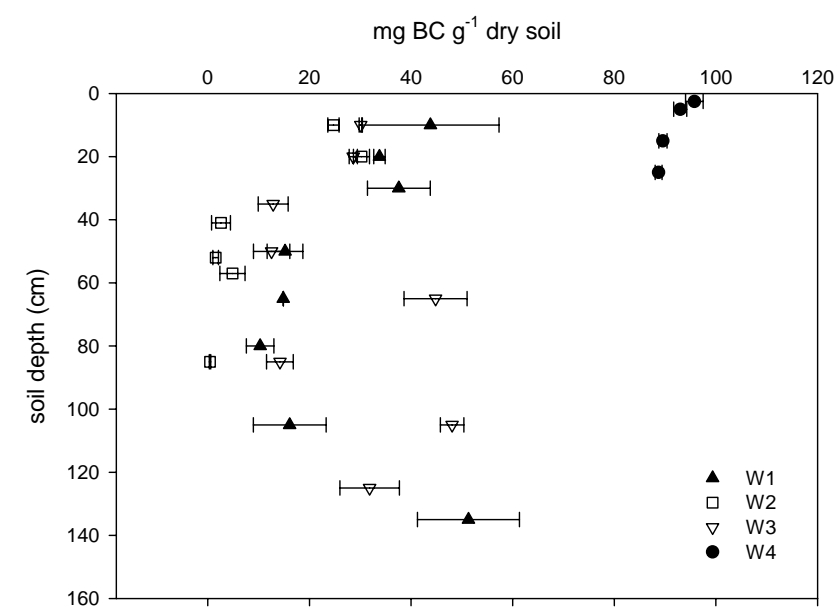

Fig. 3. BC contents plotted against soil depth for W1 to W4. Bars indicate one SE.

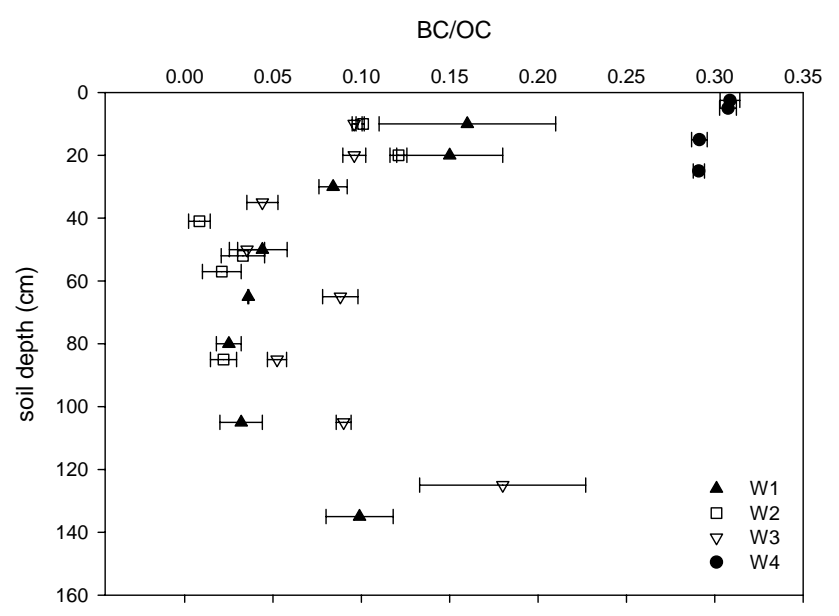

Fig. 4. BC/OC ratios plotted against soil depth for W1 to W4. Bars indicate one SE.

decreased significantly with depth at W2 and W4 (Table 2). In all profiles, ratios of $\mathrm{BC}$ to $\mathrm{OC}$ tended to decline with depth (Table 2), though this decline was non-continuous and some reverse pattern in the deeper horizons was visible in profiles W1 and W3 (Fig. 4). Black carbon concentrations and $\mathrm{BC} / \mathrm{OC}$ ratios were statistically not significantly related to $\mathrm{OC}$ contents. Peak temperature increased significantly with soil depth for W1 and W3 (Table 2, Fig. 5), and were smaller in the topsoil than in deeper horizons also for W2.

The maximum depth where $\mathrm{BC}$ could be detected was $130-140 \mathrm{~cm}$ at $\mathrm{W} 1,80-90 \mathrm{~cm}$ at $\mathrm{W} 2,120-130 \mathrm{~cm}$ at $\mathrm{W} 3$, and $30 \mathrm{~cm}$ at $\mathrm{W} 4$. At the latter, apparently humus-free sand followed the bottom line of the peat layer at around $30 \mathrm{~cm}$ depth and was not sampled. In profiles W1 and W3, where organic horizons of several decimetres thickness followed the upper body of the peat, $\mathrm{BC}$ could be detected in almost all depths. At W2, BC passed a superior mineral horizon at

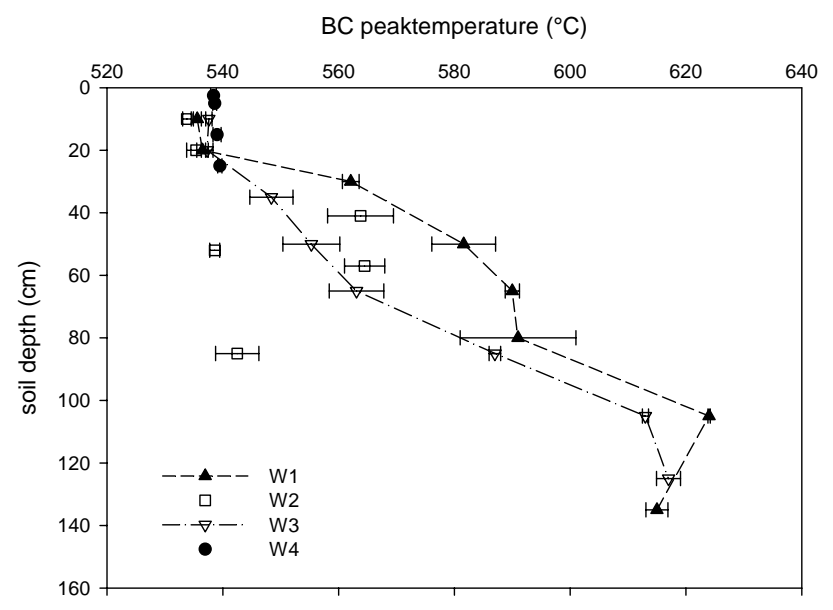

Fig. 5. BC peak temperatures plotted against soil depth for W1 to W4. Bars indicate one SE. Lines visualize the increase in peak temperature for W1 and W3 with depth. Two symbols from W2 not following the general trend are mineral interlayers.

Table 2. Correlation coefficients between soil depth and BC content, $\mathrm{BC} / \mathrm{OC}$ ratios, and $\mathrm{BC}$ peak temperatures for sites $\mathrm{W} 1$ to $\mathrm{W} 4$. Asterisks indicate level of significance.

\begin{tabular}{cccc}
\hline & BC content & BC/OC & BC peak temperature \\
\hline W1 & -0.03 & $-0.42 *$ & $0.90^{* *}$ \\
W2 & $-0.82 * *$ & $-0.74 * *$ & 0.41 \\
W3 & -0.32 & $-0.39 *$ & $0.97 * *$ \\
W4 & $-0.66^{* *}$ & $-0.59 *$ & 0.45 \\
\hline
\end{tabular}

$50 \mathrm{~cm}$. In this material, $\mathrm{BC}$ was detected at concentrations of $1.6 \mathrm{mg} \mathrm{BC}^{-1}$ soil while the underlying organic horizon contained $4.9 \mathrm{mg} \mathrm{BC} \mathrm{g}^{-1}$ soil, followed by a second mineral horizon containing 0.44 ( 0 to 0.62$) \mathrm{mg} \mathrm{BC} \mathrm{g}^{-1}$ soil.

The mean amount of $\mathrm{BC}$ as calculated from $\mathrm{BC}$ concentrations and bulk densities was 2.2, 2.5, 2.3, and $7.5 \mathrm{~kg} \mathrm{BC} \mathrm{m}^{-2}(0-30 \mathrm{~cm})$ for $\mathrm{W} 1$ to $\mathrm{W} 4$, and $4.7,0.7$, and $4.5 \mathrm{~kg} \mathrm{BC} \mathrm{m}^{-2}>30 \mathrm{~cm}$ for $\mathrm{W} 1, \mathrm{~W} 2$, and $\mathrm{W} 3$, respectively (Table 3). In other words, between 21 (W2) and 69 (W1) percent of the total $\mathrm{BC}$ has been transported below the former Hp-horizon, assuming that no direct injection of $\mathrm{BC}$ occurred during time of application. Under the assumption that the applied pyrogenic carbon was admixed with the peat by tillage in the Hp horizon $(0-30 \mathrm{~cm})$ and considering the maximum time passed (95 years), minimum transport rates for BC of 1.16 (W1), 0.63 (W2), and 1.05 (W3) $\mathrm{cm} \mathrm{a}^{-1}$ can be calculated. Taking into account measured subsidence rates of 67 to $114 \mathrm{~cm}$ since beginning of waste disposal, calculated BC transport would even become higher. 
Table 3. Mean amounts of black carbon for sites $\mathrm{W} 1$ to $\mathrm{W} 4$ added for topsoils $(0-30 \mathrm{~cm})$ and deeper horizons $(>30 \mathrm{~cm})( \pm 1 \mathrm{SE})$ and their relative shares to the total.

\begin{tabular}{ccccc}
\hline & $\mathrm{kg} \mathrm{BC} \mathrm{m}^{-2}(0-30 \mathrm{~cm})$ & $\%$ of total BC & $\mathrm{kg} \mathrm{BC} \mathrm{m}^{-2}(>30 \mathrm{~cm})$ & $\%$ of total BC \\
\hline W1 & $2.17(0.42)$ & 31 & $4.71(1.44)$ & 69 \\
W2 & $2.51(0.12)$ & 79 & $0.67(0.53)$ & 21 \\
W3 & $2.34(0.10)$ & 34 & $4.53(0.57)$ & 66 \\
W4 & $7.52(0.07)$ & n.d. & n.d. & n.d. \\
\hline
\end{tabular}

\section{Discussion}

The comparison of the virtually uncontaminated peatland at Seebodenalp with Witzwil, where historical records of pyrogenic carbon application exist clearly showed that the DSC method does not produce significant amounts of BC artefacts during measurement of organic-rich samples. This is an important requirement for the interpretation of DSC-based $\mathrm{BC}$ quantification and has not been tested for peat in the original method (Leifeld, 2007). In that study, peak temperatures of $\mathrm{BC}$ have been assigned to the continuum of products formed by the varying combustion conditions with charred residues peaking at much lower temperatures than charcoal $\left(\geq 520^{\circ} \mathrm{C}\right)$, soot $\left(>600^{\circ} \mathrm{C}\right)$, or graphite $\left(>800^{\circ} \mathrm{C}\right)$. It was found, that bituminous coal was the only non-BC material having a thermal stability similar to that of charcoal or soot, characterized by a peak temperature of $546^{\circ} \mathrm{C}$. At Witzwil, the single piece of presumably charred bituminous coal found at $\mathrm{W} 2$ was characterized by one broad peak at $573^{\circ} \mathrm{C}$. The charred nature of this material was further corroborated by small ratios of $\mathrm{H} / \mathrm{C}(0.51)$ and $\mathrm{O} / \mathrm{C}(0.04)$ indicating some contribution of inertinite (Killops and Killops, 2005). Together, the DSC measurements imply that charcoal, charred bituminous coal and soot comprise the pyrogenic carbon found in the peatland profiles.

The NMR data (Fig. 2) supported the BC quantification because Witzwil samples showed a pronounced peak at $130 \mathrm{ppm}$ both at the top and the bottom of the profiles whereas this peak was much smaller for soils from Seebodenalp. Resonances at around $130 \mathrm{ppm}$ have been ascribed to condensed aromatic BC structures, but contain also signals from plant-derived compounds such as lignin (Skjemstad et al., 1999). In general, the three BC-containing spectra resemble much of the characteristics found for burnt soils from forest stands in Spain (Knicker et al., 2006). Because our peat samples were not pre-treated to remove non-BC prior to NMR analysis (see e.g. Simpson and Hatcher, 2004), it is likely that the aromatic region in the NMR spectra also contains other aromatic compounds, which are visible in the spectra from Seebodenalp or indicated by pronounced contributions of lignin-derived methoxyl-C (55 ppm, W1 130$140 \mathrm{~cm})$.
BC quantification is strongly method-dependent and both site history and sampling methodology affects its amount, leading to considerable variation of reported $\mathrm{BC}$ contents across soils (Preston and Schmidt, 2006). Because at Witzwil both the technique of $\mathrm{BC}$ application and the nature of the $\mathrm{BC}$ may differ from formation pathways and characteristics of $\mathrm{BC}$ produced by natural vegetation fires, conclusions with respect to the fate of $\mathrm{BC}$ in soil can be drawn with caution only. Amounts of BC at Witzwil, cumulated over the whole profiles, ranged from 3.2 to $7.5 \mathrm{~kg} \mathrm{~m}^{-2}$, corresponding to $\mathrm{BC} / \mathrm{OC}$ ratios of 0.02 to 0.3 . These quantities exceed those typically produced during single vegetation fire events. The amount of BC measured in six studies in boreal and temperate regions as visual char after single forest fires (experimental or under controlled conditions, i.e. referring to actual char production rates and excluding "old" char) ranged from 0.024 to $0.74 \mathrm{~kg} \mathrm{~m}^{-2}$ (Preston and Schmidt, 2006). Similarly, Alexis et al. (2007) reported char production rates of $0.14 \mathrm{~kg} \mathrm{BC} \mathrm{m}^{-2}$ in a Florida scrub-oak ecosystem. Much greater increases in site charcoal $(<2 \mathrm{~mm}$, to $30 \mathrm{~cm}$ depth) of 2 to $18 \mathrm{~kg} \mathrm{~m}^{-2}$ were reported by Hopmans et al. (2005) after clearfelling and burning of two Eucalyptus sites in Australia. Together, BC input rates from single fires in most of these studies are typically one to two orders of magnitude below that what we found as BC stocks though similar levels can be achieved in individual cases. In general, it must be considered that soils in the cited studies were typically not sampled deeper than a few decimetres and that fine char fragments and dissolved $\mathrm{BC}$ were not always captured, implying smaller estimates as compared to DSC where all of the BC is captured. In addition, measured BC contents at Witzwil are the result of multiple applications over several decades rather than from a single fire event.

The data cited above suggest that typically numerous fire events are needed to produce quantities of $\mathrm{BC}$ comparable to those measured at Witzwil. None of the cited studies has been dedicated to the fate of $\mathrm{BC}$ in organic soils, though peatland fires substantially affect global $\mathrm{C}$ fluxes and contribute probably also to the formation of BC. For example, large and severe peatland fires have been reported for Indonesia, where more than 2.5 Mha burnt in 1997 and released 0.19 to $0.23 \mathrm{GtCO}_{2}-\mathrm{C}$ (Page et al., 2002). The same authors estimated that those fires consume on average the upper $0.5 \mathrm{~m}$ of 
peat. Even if currently unexplored, we suggest that some BC is formed during such huge fires. The following general conclusions aim at improving our understanding of the fate of pyrogenic carbon in organic soils also for these ecosystems.

For the deep organic profiles W1-W3 we estimated BC transportation rates of 0.6 to $1.2 \mathrm{~cm} \mathrm{a}^{-1}$. This calculation relies on the assumption that the $\mathrm{BC}$ quantified in the deeper soil stems from waste application and is no inherent property of the peat. Based on i) the comparison to uncontaminated sites at Seebodenalp showing no evidence for formation of $\mathrm{BC}$ artefacts during measurement, ii) the high concentrations in the deeper soil exceeding those of many sites containing $\mathrm{BC}$ from vegetation fires, iii) the high thermal stability referring to a soot- or coal-like nature of the $\mathrm{BC}$ and iv) the historical record of waste application, we argue that this assumption is reliable though no transport experiments have been carried out. Our estimated transportation rates exceed those reported for mineral soils at least by a factor of 20 (Carcaillet, 2001). Drained fens are typically characterized by pore volumes of up to $80 \%$ even in the topsoil (Zeitz and Velty, 2002). Pore volumes of around 60 to $70 \%$ in topsoil samples from Witzwil thus indicate a pronounced physical degradation of the peat but are still greater than in most mineral soils. Our organic soils may have been more porous in earlier years when the peat was less degraded and thus closer to values found today in the deep soil. We suggest that the large pore volume of up to $91 \%$ together with the often saturated conditions in the deeper horizons, and occasionally also in the topsoil, likely favoured rapid movement of BC in soluble or particulate form downwards the profile. The effect of pore volume on the mobility of $\mathrm{BC}$ is further collaborated by results from $\mathrm{W} 2$ where mineral interlayers interrupted the peat deposit. BC contents dropped sharply above the first mineral interlayer where pore volumes declined from $>75$ to $57 \%$ though some of the BC moved deeper. It is likely, that the reduced porosity decreased the rate of water flow through the profile. Together, these results indicate that the vertical transport of $\mathrm{BC}$ is favoured by a high soil pore volume and the availability of free water as found frequently in organic soils. Soil water has been held responsible also for the distribution of BC in mineral soils. Rodionov et al. (2006) detected BC down to $90 \mathrm{~cm}$ in some steppe soils from Russia. The authors showed that the distribution of $\mathrm{BC}$ with depth depended on climate with cold, moist sites having a more intensive transport downwards the profile than warm and dry ones and attributed this pattern to difference in soil water flows.

Because of the poor conditions for microbial activity in permanently water-saturated and thus anaerobic peat horizons, the rapid movement of $\mathrm{BC}$ into this zone may lead to an accumulation of $\mathrm{BC}$ in the longer term, as probably already occurring in profile $\mathrm{W} 1$, where $\mathrm{BC}$ concentration at $130 \mathrm{~cm}$ depth exceeds that in the topsoil. The high transportation rates as compared to the literature imply that physical stabilisation of BC in organic horizons is negligible or weak. However, the applied methods give no conception on whether BC is dislocated in soluble or particulate form, or both. For a site under Podzol, Hockaday et al. (2006) concluded that fragmentation and dissolution of charcoal BC occurs on a centennial timescale through oxidation of the condensed aromatic ring structures, favouring soluble transport.

We observed a systematic and pronounced increase in BC peak temperatures with depth for two of our profiles, W1 and W3. The composition and origin of BC cannot be derived directly from its thermal stability, but previous results indicated that well-ordered BC of higher crystallinity is thermally also more stable (Leifeld, 2007). Two possible mechanisms, alone or in combination may explain this shift in thermal stability of BC with depth. Firstly, it may reflect the preferential transport of distinct BC species through the soils pore volume downwards, either because the interaction of $\mathrm{BC}$ with the soils matrix is related to chemical $\mathrm{BC}$ characteristics or because density and particle size differ between thermally labile and stable BC. Secondly, the shift in peak temperature may be the result of a stronger oxidation of BC in the soils upper horizon where both microbial activity and oxygen supply is higher. This mechanism would be causative if biological or chemical $\mathrm{BC}$ oxidation reduces the thermal stability of BC.

\section{Conclusions}

Pyrogenic carbon is highly mobile in peatland soils and covers distances of up to one meter within a few decades. During translocation, BC is separated into different species and sootlike $\mathrm{BC}$ accumulates more rapidly in the deeper horizons of the soil. Because of the unfavourable conditions for oxidative decay, injection of $\mathrm{BC}$ in deep peat deposits likely contributes to its long-term exclusion from active carbon cycling and favours its access to the geological carbon cycle.

Acknowledgements. Thanks to P. Trachsel for logistical support in the field and information on land-use history, R. Giger and R. Schafflützel for help in the lab and H. Knicker for NMR-analysis. This study was partially funded by the Swiss Federal Office for Environment.

Edited by: J. Kesselmeier

\section{References}

Alexis, M. A., Rasse, D. P., Rumpel, C., Bardoux, G., Péchot, N., Schmalzer, P., Drake, B., and Mariotti, A.: Fire impact on C and $\mathrm{N}$ losses and charcoal production in a scrub oak ecosystem, Biogeochem. 82, 101-116, 2007.

Carcaillet, C.: Are Holocene wood-charcoal fragments stratified in alpine and subalpine soils? Evidence from the alps based on AMS C-14 dates, Holocene, 11, 231-242, 2001.

Cheng, C. H., Lehmann, J., Thies, J. E., Burton, S. D., and Engelhard, M. H.: Oxidation of black carbon by biotic and abiotic processes, Org. Geochem., 37, 1477-1488, 2006. 
Dai, X., Boutton, T. W., Glaser, B., Ansley, R. J., and Zech, W.: Black carbon in a temperate mixed-grass savanna, Soil Biol. Biochem., 37, 1879-1881, 2005.

Gustafsson, O., Bucheli, T. D., Kukulska, Z., Andersson, M., Largeau, C., Rouzaud, J. N., Reddy, C. M., and Eglinton, T. I.: Evaluation of a protocol for the quantification of black carbon in sediments, Global Biogeochem. Cy., 15, 881-890, 2001.

Gutknecht-Mäder, U.: Berner ,Ghüder' im Grossen Moos, in: Seebutz, Heimatbuch des Seelandes und Murtenbiets, edited by: W. Gassmann AG, Biel, Switzerland, pp. 57-61, 1998.

Hockaday, W. C., Grannas, A. M., Kim, S., and Hatcher, P. G.: Direct molecular evidence for the degradation and mobility of black carbon in soils from ultrahigh-resolution mass spectral analysis of dissolved organic matter from a fire-impacted forest soil, Org. Geochem., 37, 501-510, 2006.

Hopmans, P., Bauhus, J., Khanna, P., and Weston, C.: Carbon and nitrogen in forest soils: Potential indicators for sustainable management of eucalypt forests in south-eastern Australia, For. Ecol. Manage., 220, 75-87, 2005.

Killops, S. and Killops, V.: Introduction to organic geochemistry, Blackwell Publishing, Malden, USA, pp. 393, 2005.

Knicker, H. and Lüdemann, H. D.: N-15 and C-13 CPMAS and solution NMR-studies of $\mathrm{N}-15$ enriched plant material during 600 days of microbial degradation, Org. Geochem., 23, 329-341, 1995.

Knicker, H., Almendros, G., Gonzalez-Vila, F. J., Gonzalez-Perez, J. A., and Polvillo, O.: Characteristic alterations of quantity and quality of soil organic matter caused by forest fires in continental Mediterranean ecosystems: a solid-state C-13 NMR study, Eur. J. Soil Sci., 57, 558-569, 2006.
Kuhlbusch, T. A. J.: Black carbon and the carbon cycle, Science, 280, 1903-1904, 1998.

Leifeld, J.: Thermal stability of black carbon characterized by oxidative differential scanning calorimetry, Org. Geochem., 38, 112-127, 2007.

Page, S. E., Siegert, F., Rieley, J. O., Boehm, H. D. V., Jaya, A., and Limin, S.: The amount of carbon released from peat and forest fires in Indonesia during 1997, Nature, 420, 61-65, 2002.

Preston, C. M. and Schmidt, M. W. I.: Black (pyrogenic) carbon: a synthesis of current knowledge and uncertainties with special consideration of boreal regions, Biogeosciences, 3, 397-420, 2006, http://www.biogeosciences.net/3/397/2006/.

Rodionov, A., Amelung, W., Haumaier, L., Urusevskaja, I., and Zech, W.: Black carbon in the zonal steppe soils of Russia, J. Plant Nutr. Soil Sci., 169, 363-369, 2006.

Rumpel, C., Alexis, M., Chabbi, A., Chaplot, V., Rasse, D. P., Valentin, C., and Mariotti, A.: Black carbon contribution to soil organic matter composition in tropical sloping land under slash and bum agriculture, Geoderma, 130, 35-46, 2006.

Simpson, M. J. and Hatcher, P. G.: Overestimates of black carbon in soils and sediments, Naturwissenschaften, 91, 436-440, 2004

Skjemstad, J. O., Taylor, J. A., Janik, L. J., and Marvanek, S. P. Soil organic carbon dynamics under long-term sugarcane monoculture, Aust. J. Soil Res., 37, 151-164, 1999.

Zeitz, J. and Velty, S.: Soil properties of drained and rewetted fen soils, J. Plant Nutr. Soil Sci., 165, 618-626, 2002. 